Adam Franke**

https://orcid.org/0000-0002-9104-1021

\title{
Przygody Alicji w krainie Tima Burtona. Filmowa adaptacja opowieści Lewisa Carrolla w świetle Campbellowskiej koncepcji monomitu
}

\section{Abstrakt:}

W artykule przeprowadzono analizę filmu Alicja w Krainie Czarów (2010), wyreżyserowanego przez Tima Burtona, jako realizacji Campbellowskiego schematu narracyjnego wyprawy bohatera. Burton, a także scenarzystka, Linda Wolvertoon, potraktowali literackie pierwowzory autorstwa Lewisa Carrolla $(1865,1871)$ jedynie jako punkt wyjścia do przedstawienia autorskiej wizji. W prezentowanych rozważaniach zaproponowano interpretację filmowej postaci Alicji jako bohaterki mitycznej, która musi zyskać samoświadomość i przejść wewnętrzną metamorfozę

- transgresję z zagubionej panienki w odważną wojowniczkę o własną autonomię.

\section{Słowa kluczowe:}

adaptacja, Alicja w Krainie Czarów, film dziecięcy i młodzieżowy, Joseph Campbell, Lewis Carroll, monomit, O tym, co Alicja odkryła po drugiej stronie Lustra, Przygody Alicji w Krainie Czarów, sequel, Tim Burton, wyprawa bohatera

\section{Alice's Adventures in Tim Burton's Land: The Film} Adaptation of the Stories by Lewis Carroll in the Light of the Campbellian Concept of the Monomyth

\section{Abstract:}

The aim of the article is to analyse Tim Burton's film Alice in Wonderland (2010) as exploiting Joseph Campbell's model of the hero's journey. Burton, as well as the

* Weronika Kostecka - dr, pracuje w Instytucie Literatury Polskiej Wydziału Polonistyki na Uniwersytecie Warszawskim. Jej zainteresowania badawcze obejmują historię oraz teorię literatury dziecięcej, kulturową historię baśni oraz literaturę i kulturę popularną. Kontakt: w.kostecka@uw.edu.pl.

** Adam Franke - mgr, przygotowuje rozprawę doktorską w Instytucie Literatury Polskiej Wydziału Polonistyki na Uniwersytecie Warszawskim dotyczącą gnostyckiej wizji świata w literaturze XX wieku. Kontakt: afranke@uw.edu.pl. 
screenwriter, Linda Wolvertoon, treated the original works by Lewis Carroll $(1865,1871)$ only as a starting point to present their own vision. In the presented considerations, the authors propose the interpretation of the film incarnation of Alice as a mythical heroine who must gain self-awareness and undergo an internal metamorphosis - a transgression from a lost girl into a brave warrior for her own autonomy.

Key words:

adaptation, Alice in Wonderland, children's and young adult film, Joseph Campbell, Lewis Carroll, monomyth, Through the Looking-Glass, and What Alice Found There, Alice's Adventures in Wonderland, sequel, Tim Burton, hero's journey

W śród licznych - szeroko pojmowanych - adaptacji literatury dziecięcej i młodzieżowej, które na początku XXI stulecia trafiły na ekrany kin, znajduje się ekranizacja opowieści Lewisa Carrolla o przygodach Alicji wyreżyserowana przez Tima Burtona - twórcę uznawanego za wizjonera i jednego z najbardziej charakterystycznych, awangardowych oraz ekscentrycznych artystów współczesnego kina (Davis, 2016, s. 149-150; Kérchy, 2016, s. 30; Zipes, 2016a, s. 282-285). Scenariusz, na podstawie którego powstał film Alicja w Krainie Czarów (Zanuck, Roth, Todd, Todd, Burton, 2010) z Mią Wasikowską w roli tytułowej, napisała związana ze studiem Walta Disneya Linda Wolvertoon. Ze współpracy tych dwojga utytułowanych twórców zrodził się obraz przedstawiający Carrollowskie $\left(1865,1871^{1}\right)$ historie o Krainie Czarów i świecie za Lustrem w zupełnie nowym świetle. Jest on przez wielu badaczy zaliczany do tych ekranizacji literatury dziecięcej, które wymykając się konwencjom estetycznym, schematom fabularnym, wzorcom genderowym czy też strategiom komunikacji z potencjalnym młodym odbiorcą ${ }^{2}$, stanowią kulturową alternatywę dla stylu od lat dominującego w hollywoodzkich adaptacjach $\mathrm{i}$, generalnie rzecz biorąc, mainstreamowych produkcjach filmowych dla młodych odbiorców (Davis, 2016, s. 141-154; McCallum, 2018, s. 87-88; Zipes,

1 Przygody Alicji w Krainie Czarów „oficjalnie” wydano po raz pierwszy 26 listopada 1865 roku. Choć na egzemplarzach widniał rok 1866, to istniała również inna edycja, odrzucona przez Carrolla z uwagi na jej niezadowalającą jego zdaniem jakość, a wydrukowana $\mathrm{z}$ datą 1865. Powieść O tym, co Alicja odkryła po drugiej stronie Lustra została zaś opublikowana 27 grudnia 1871 roku, a na karcie tytułowej wszystkich kopii jako rok wydania zamieszczono 1872 .

2 O wizjonerskim zastosowaniu przez Burtona technologii 3D oraz o paraleli między nowatorskimi strategiami kształtowania narracji przez tego reżysera oraz przez Carrolla pisze Anna Kérchy (2016, s. 64-74). 
2016b, s. 4) ${ }^{3}$. Tym samym dzieło Burtona i Wolvertoon stanowi istotny element wciąż rozrastającego się uniwersum adaptacji dylogii Carrolla.

Badacze niejednokrotnie podnosili kwestię wyjątkowego potencjału obu powieści jako tekstów kultury szczególnie inspirujących twórców do podejmowania różnorodnych intertekstualnych gier. Przykładowo, Anna Kérchy (2016) określa Alicję jako złożoną bohaterkę frapującą nie tylko naukowców, „postać ikoniczną o trwałym wpływie na sztukę" (s. 1) ${ }^{4}$, natomiast Alicja Ungeheuer-Gołąb (2014) dowodzi, że opowieść Carrolla „odbiła się [...] echem w ponadstuletniej historii ludzkiej kultury, w różnych dziedzinach sztuki i życia społecznego. [...] stała się tworzywem dla tak wielu i tak różnorodnych artystów. Odniesienia bowiem do jej postaci i przygód można znaleźć w literaturze, malarstwie, muzyce, tańcu, fotografii, teatrze, filmie, w sztukach użytkowych" (s. 126). Z kolei Maria Tarnogórska (2016) zwraca uwagę na wpływ dylogii także na obszar pozaartystyczny: „Uchodząca za najczęściej, tuż po spuściźnie Szekspira, cytowane dzieło literatury angielskiej, nie przestaje zadziwiać możliwością coraz to nowych odczytań i intertekstualnych adaptacji, z równą intensywnością przenikając do sfery artystycznego przekazu, co do refleksji naukowej i filozoficznej, reprezentującej różnorodne nurty i tradycje” (s. 53). Ponadstuletnią tradycję mają także filmowe adaptacje dzieła Carrolla ${ }^{5}$. Jak pisze Małgorzata Jakubowska (2015):

3 Przy czym nie wszyscy badacze podzielają pogląd o niekonwencjonalnym charakterze filmu Burtona. Zdaniem Małgorzaty Jakubowskiej (2015), „trzeba [...] pamiętać, iż film Alice in [...] Wonderland odnawiał współpracę artysty ze Studiem Disneya - a to niestety oznaczało, iż dzieło zostanie poddane presji producentów i "przykrojone« do gustu familijnej publiczności. W konsekwencji Burton zaprezentował widzom kontynuację wizji Disnejowskiej, choć wskazywał na inspiracje filmem [Jana] Švankmajera i poetyką surrealistyczną" (s. 66). Na temat wspomnianego przez autorkę filmu, czyli Coś z Alicji (Fueter, Švankmajer, 1988), zob. np. Kérchy (2016, s. 168-187).

4 Jeśli nie podano inaczej, wszystkie tłumaczenia autorów artykułu - Weroniki Kosteckiej i Adama Frankego.

5 O telewizyjnych i kinowych adaptacjach dylogii Carrolla - wśród których słynna Disnejowska animacja (Disney, Geronimi, Jackson, Luske, 1951) jest tylko jednym z rozlicznych wariantów, choć przypuszczalnie najbardziej utrwalonym w popkulturowej pamięci odbiorców - nierzadko niekonwencjonalnych pod względem estetyki czy konceptów fabularnych, pisze m.in. Will Brooker (2004) w swojej monografii poświęconej popkulturowym wyobrażeniom o życiu Carrolla i jego dziele (zwłaszcza w rozdziale zatytułowanym Adapting Alice). Nie tylko o filmowych, lecz także o animowanych, fotograficznych, teatralnych i komiksowych adaptacjach Alicji... można z kolei przeczytać w monografii pod redakcją Sissi Helff i Nadii Butt (2016). Publikacja Anny Kérchy (2016) dostarcza zaś informacji o transmedialnym życiu opowieści Carrolla w muzyce, aplikacjach na iPada, grach komputerowych, fikcjach fanowskich, balecie czy performansach body art. Bogactwu 
[...] pierwsza ekranizacja powstała w Wielkiej Brytanii już w kilka lat po wynalezieniu ruchomych fotografii, gdy tylko kino zaczęło swoje próby opowiadania obrazem. Zachowany jedynie we fragmentach film Cecila M. Hepwortha z 1903 roku był jedną z pierwszych produkcji filmowych, w której zastosowano efekty specjalne. Kolejne filmowe wersje powstawały w najróżniejszych rejonach świata, także w Australii, ZSRR i Japonii. Były utrzymane w przeróżnych konwencjach: od komedii, poprzez musical, aż po horror. Ekranizacje układają się w spektrum różnorodnych założeń i koncepcji adaptacji: od utworów poszukujących pełnej zgodności z oryginałem, po „twórcze zdrady" i dzieła swobodnie nawiązujące do powieści. Wśród filmów poświęconych Alicji można znaleźć takie, które wykorzystują strategie transpozycji, transformacji, komentarza, analogii, renarracji, refabularyzacji - za pomocą tych dzieł można zegzemplifikować wszelkie rozwiązania opisane w teoriach adaptacji (s. 60).

W kontekście literackiego pierwowzoru film Burtona to w gruncie rzeczy nowa opowieść. Określany bywa zresztą jako sequel ${ }^{6}$ (McCallum, 2018, s. 94), a więc kontynuacja i dopełnienie historii już znanej odbiorcom (o ile opisane przez Carrolla przygody Alicji w Krainie Czarów oraz po drugiej stronie Lustra potraktujemy jako całość). Zarówno sequel, jak i prequel (czyli opowieść, której akcja rozgrywa się przed wydarzeniami prezentowanymi w oryginalnym tekście kultury), to - jak wyjaśnia Kamila Kowalczyk (2014) - „terminy używane głównie w odniesieniu do dzieł powstających w obrębie jednego medium" (s. 39). Możliwe są jednak odstępstwa od tej zasady, gdy „mamy do czynienia ze specyficznym retellingiem $\mathrm{w}$ wariancie prequelowym lub sequelowym, pozwalającym na rozróżnienie czasowe opisywanych zdarzeń i ich następstw" (s. 39) - renarracją ${ }^{7}$ w wersji sequelowej jest właśnie Alicja w Krainie Czarów w reży-

transmedialnych adaptacji dylogii poświęcone są też rozmaite publikacje popularnonaukowe, np. opracowanie autorstwa Catherine Nichols (2014).

6 Hugh H. Davis (2016, s. 141) nazywa film Burtona pseudosequelem i dowodzi, że jak mieszkańcy magicznej krainy polegają na Alicji powoli przypominającej sobie swoją poprzednią wizytę poprzez udział w nowych, choć podobnych przygodach, tak reżyser buduje swoją narrację, oczekując, że potencjalni widzowie przypomną sobie wcześniejsze adaptacje literackiego pierwowzoru.

7 W innej publikacji Kowalczyk (2016) tłumaczy, że renarracje to „takie teksty kultury, które bazują przede wszystkim na zakorzenionym w masowej wyobraźni [...] wzorcu [...], przekształcając wszystkie cechy formy tradycyjnej, proponując finalnie odbiorcy nową, w sposób twórczy przekształconą jej wersję" (s. 6). Maciej Skowera (2016) uznaje natomiast retelling i rewriting za „dwie zasadnicze - ale różniące się pod względem statusu materiału źródłowego - formy renarracji, rozumianej tu jako szersza kategoria, która obejmuje wszelkie rodzaje twórczego prze-rabiania jakiejś narracji. Podczas gdy rewriting wymaga 
serii Burtona. Akcja filmu dzieje się trzynaście lat po wydarzeniach opisanych $\mathrm{w}$ dylogii, mimo że zawiera wątki fabularne pojawiające się w oryginale. Utwór Carrolla został więc tutaj potraktowany jedynie jako punkt wyjścia do przedstawienia autorskiej wizji.

Kluczową zmianą, jaką wprowadzili Burton i Wolvertoon, jest wplecenie w opowieść o Alicji opisanego przez Josepha Campbella schematu wędrówki bohatera mitycznego (Franke, 2015, s. 49) ${ }^{8}$. Aby w pełni zrozumieć treść i znaczenie tej ekranizacji, niezbędne jest zatem prześledzenie, jak ów wzorzec został wykorzystany w filmowej wersji perypetii Alicji w Krainie Czarów ${ }^{9}$. W słynnej monografii pt. Bohater o tysiącu twarzy Campbell (1949/1997) w dogłębny spo-

pierwowzoru w postaci jednostkowego, oryginalnego tekstu w formie pisanej, retelling odsyła nas do sytuacji ustnego opowiadania - oczywiście formuła ta siłą rzeczy bazuje na tekstualnych reprezentacjach historii funkcjonujących niegdyś najpewniej w formie oralnej, ale ważne jest przede wszystkim to, że do źródeł poszczególnych tematów, fabuł i motywów nie sposób dotrzeć" (s. 53).

8 Na temat krytyki teorii Campbella jako nieuniwersalnej, bo mającej zastosowanie jedynie w przypadku protagonistów płci męskiej, zob. Lasoń-Kochańska (2005, s. 195-196). Autorzy tego artykułu postrzegają jednak koncepcję monomitu jako interesujący trop interpretacyjny również w przypadku Burtonowskiej Alicji jako bohaterki odbywającej mityczną wędrówkę. Sam Campbell (1949/1997) argumentował: „Cały sens wszechobecnego mitu o wędrówce bohatera sprowadza się do tego, że ma on służyć zarówno mężczyznom, jak i kobietom jako ogólny wzorzec, i to bez względu na to, jakie miejsce zajmuje każde z nich na wytyczonej według niego skali. Dlatego właśnie wyrażony jest on w terminach o najszerszym znaczeniu" (s. 96). Kristin Bovaird-Abbo (2014, s. 37) dowodzi, że mimo iż Campbell koncentruje się na bohaterach męskich, jego koncepcja bohatera i wyprawy bohaterskiej daje się odnieść - choć z pewnymi zastrzeżeniami - do obu płci. Możliwość zastosowania tej koncepcji w analizach feministycznych, dotyczących kobiet jako bohaterek, dostrzega także Sarah Nicholson (2011). Z kolei Maureen Murdock (1990) zaprezentowała autorską koncepcję schematu kobiecej wyprawy bohaterskiej, składającej się z następujących elementów: oddzielenie od kobiecości - identyfikacja z męskością - droga prób - pozorny sukces - możliwość powiedzenia „nie” - inicjacja i spotkanie z boginią - tęsknota za kobiecością - rozwiązanie konfliktu między matką i córką - odnalezienie „wewnętrznego mężczyzny” - zintegrowanie w sobie męskości i kobiecości.

9 Dylogia Carrolla była z kolei niejednokrotnie analizowana za pomocą Proppowskiego (1928/2011) schematu bajki magicznej (choć sama Alicja... nie może być uznana za baśń; Kostecka, 2014, s. 182) - zob. np. Sundmark (1999, s. 39 i nast.). Jak wyjaśnia Łukasz Musiał (2016), „analizy Władimira Proppa znalazły swoją nową postać w miejscami mocno uproszczonej, miejscami zaś wzbogaconej o nowe wątki popularnej książce Bohater o tysiącu twarzy [...] Josepha Campbella. Odwołując się do przykładów zaczerpniętych z różnych kultur świata, Campbell, podobnie jak Propp, choć metodami zdecydowanie mniej ścisłymi i formalistycznymi, próbuje dokonać rekonstrukcji tzw. monomitu o bohaterze" (s. 93). 
sób analizuje wzorcowy schemat wyprawy bohaterskiej, który nazywa monomitem. Powracającą w mitach wielu kultur oś fabularną (oddzielenie - inicjacja - powrót) określa zaś mianem jądra monomitu. W swojej najbardziej klarownej postaci schemat ten jest dość prosty: „Bohater ryzykuje wyprawę ze świata powszedniości do krainy nadnaturalnych dziwów; spotyka tam fantastyczne siły i odnosi rozstrzygające zwycięstwo, po czym powraca z tej tajemniczej wyprawy obdarzony mocą czynienia dobra ku pożytkowi swoich bliźnich” (s. 3). Jak przekonuje badacz, przykładów obrazujących schemat monomitu można odnaleźć wiele:

Prometeusz wspiął się do nieba, ukradł bogom ogień i wrócił na ziemię. Jazon przepłynął między zgniatającymi statki skałami, przechytrzył smoka strzegącego złotego runa i powrócił z runem i mocą potrzebną do tego, by odebrać uzurpatorowi należny mu tron. Eneasz zszedł do Hadesu, przeprawił się przez budzącą przerażenie rzekę umarłych, okupił się trzygłowemu psu, Cerberowi, strzegącemu wejścia do podziemnej krainy i porozmawiał z cieniem zmarłego ojca, który odkrył przed nim wszystkie tajemnice: los dusz, los Rzymu, który Eneasz miał wkrótce założyć, i pouczył o tym, ,jakich klęsk ma uniknąć, jakie przetrwać ciosy". Potem przez bramę z kości słoniowej powrócił do swoich zadań na tym świecie (Campbell, 1949/1997, s. 34).

Pierwszy etap w Campbellowskiej koncepcji jądra monomitu to, jak już wspomniano, czas oddzielenia. Bohater musi porzucić sferę dobrze mu znaną: społeczność, w której dorastał, czy też świat, który uznaje za rzeczywisty, aby mógł - wspierany przez przychylne mu siły zewnętrzne - wkroczyć na drogę w nieznane. Etap drugi to inicjacja. Jest on kluczową częścią monomitycznej wyprawy, ponieważ bohater podlega wówczas przemianie: doznaje oświecenia (przykładem mogą być tutaj objawienia Buddy czy próby Jezusa Chrystusa na pustyni zakończone zwycięstwem nad Szatanem), umiera i zmartwychwstaje lub też zdobywa nadnaturalną moc. Ostatnim etapem podróży jest powrót. Stanowi on zarówno zakończenie monomitu, jak i, zgodnie ze swoją nazwą, powrót do punktu wyjścia w historii bohatera. Jako nowy, odmieniony człowiek, protagonista wkracza raz jeszcze do swojego świata już jako osoba oświecona czy też posiadacz niezwykłych mocy. Według Campbella wyobrażenia mitu wyprawy różnią się między sobą w zależności od poszczególnych historii charakterystycznych dla danej kultury i danego czasu. Różnice te nadają opowieści oryginalne cechy, wzbogacają ją, jednocześnie nie zmieniając schematu fabularnego samego mitu. Badacz uważał także, że elementy różnicujące poszczególne narracje mityczne powtarzają się w obrębie niezwiązanych ze sobą kultur - co, jego zdaniem, dowodzi, że opowieści te mają uniwersalny 
charakter. Taka właśnie uniwersalność cechuje również ekranizację przygód Carrollowskiej bohaterki ${ }^{10}$.

W filmowej wizji Burtona wędrówka Alicji rozpoczyna się w czasie dla niej szczególnym. Podczas wystawnego przyjęcia bohaterce oświadcza się Hamish (Leo Bill), syn biznesowego partnera jej ojca - młodzieniec, którego nie darzy ona sympatią (przypomnijmy, że protagonistka Burtona nie jest już dzieckiem, nie przekroczyła także progu dorosłości; znajduje się w okresie życia predestynującym ją do podjęcia inicjacyjnej wyprawy). Skrępowana i wystraszona niechcianą sytuacją ${ }^{11}$, dziewczyna ucieka i rusza za intrygującym ją Białym Królikiem (Michael Sheen), którego widzi jedynie ona. W pogoni za zwierzęciem wpada do nory, przenosząc się poza granice znanego sobie świata (choć przecież zawsze czuła się w jakiś sposób inna i wyobcowana) ${ }^{12}$. Ów Biały Królik symbolicznie zwiastuje nadchodzącą wyprawę - wyprowadza on główną bohaterkę z jej świata i czasu rzeczywistego i wprowadza ją do świata nieznanego oraz czasu mitycznego. Upadając w głąb króliczej nory, Alicja rozpoczyna etap nazywany przez Campbella przekroczeniem progu (Franke, 2015, s. 50). Przemierzając, jak jej Carrollowska odpowiedniczka, kolejne przestrzenie - jak komnata, której sufit został zamieniony z podłogą - orientuje się, że trafiła do krainy rządzącej się zupełnie innymi prawami niż te, do których przywykła. Aby zmieścić się w miniaturowych wrotach prowadzących poza tajemnicze pomieszczenie, bohaterka kilkakrotnie transformuje, metodą prób i błędów, swoje ciało. Tak rozpoczyna się jej inicjacyjna wędrówka: gdy Alicji udaje się wydostać na otwartą przestrzeń, podejmuje wyprawę, której głównym celem jest odnalezienie prawdziwej tożsamości. Upadek w głąb króliczej nory odpowiada analizowanemu przez Camp-

10 Warto zauważyć, że czerpanie inspiracji z Campbellowskiej koncepcji monomitu przy kreowaniu narracji w kinie rozrywkowym jest strategią stosowaną co najmniej od czasów wykreowanej przez George’a Lucasa franczyzy Gwiezdne wojny. Weronika Łucyk (2017) wskazuje, że „George Lucas stworzył Gwiezdne [w]ojny w oparciu o książkę Campbella, podobny schemat znajduje odzwierciedlenie w Matriksie czy sadze o Harrym Potterze. Nie bez przyczyny Christopher Vogler [1992/2009], amerykański scenarzysta, napisał podręcznik Podróż autora. Struktury mityczne dla scenarzystów i pisarzy. W monomitycznej opowieści typ bohatera i wewnętrzna struktura fabularna pozostają takie same, zatem oglądamy podobną historię, tylko w innym uniwersum - zmienionym czasie, przestrzeni czy rzeczywistości społeczno-gospodarczej” (s. 54). O Gwiezdnych wojnach w odniesieniu do koncepcji Campbella zob. też Żurek (2010).

11 To zresztą motyw nieraz pojawiający się w baśniach (bohaterka znajdująca się w trudnej - granicznej - sytuacji związanej z koniecznością wyboru partnera czy też akceptacji partnera jej narzuconego, a przez nią niechcianego, zmagająca się z presją zamążpójścia itd.).

12 Przy czym sytuacja, która staje się udziałem Burtonowskiej Alicji, jest nietypowa i dla niej nowa - jak była już o tym mowa, bohaterka staje w obliczu niechcianych zaręczyn. 
bella motywowi połknięcia przez wieloryba, który badacz ów rozpatrywał jako moment przejścia, porzucenia przez bohatera swojego dotychczasowego „ja” i zainicjowania redefinicji samego siebie (s. 52).

Krocząc po ścieżkach magicznego świata, Alicja napotyka na swojej drodze kolejne niezwykłe postacie. Nie jest zaskoczona ani ich obecnością, ani przebiegiem zdarzeń, uznaje bowiem toczącą się przygodę za wytwór swojej wyobraźni lub sen. Mieszkańcy Krainy Czarów - u Burtona noszącej nazwę nie Wonderland, lecz Underland ${ }^{13}$ - starają się wydedukować, czy dziewczyna jest wyczekiwaną w ich świecie Alicją, mityczną bohaterką, według legendy mającą się w końcu ujawnić:

Mówiący Kwiat: Mało podobna.

Mysz: Bo to nie ta Alicja.

Dyludam: Jeśli jest, to by mogła być.

Dyludi: Ale jak nie była[,] to nie jest.

Tweedledum: Ale jak tak, to czemu nie?

Tweedledee: Tak, tylko, że nie.

Alicja: Jak mam być nie tą Alicją, skoro to mój sen? Kim wy w ogóle jesteście? (Zanuck, Roth, Todd, Todd, Burton, 2010) ${ }^{14}$.

Status Alicji jest wciąż niejasny, bohaterka staje więc przed obliczem Gąsienicy o imieniu Absolem (Alan Rickman) - postaci pełniącej funkcję mitycznego mędrca:

Absolem: Ktoś ty?

Alicja: Absolem?

Absolem: Nie Absolem. Jam Absolem. Pytanie brzmi: kim jesteś ty?

Alicja: Alicją.

Absolem: To się okaże.

Alicja: Co to ma znaczyć? Chyba wiem kim jestem.

Absolem: Chyba czy na pewno[,] tępe dziecię? Rozwińcie Rokrocznium (Zanuck, Roth, Todd, Todd, Burton, 2010).

Absolem zapoznaje Alicję z treścią Rokrocznium (pergaminu, na którym zapisano legendę związaną z jej nadejściem). Jak przystało na bohatera opowieści mitycznej, dziewczyna ma wyzwolić krainę z rąk niegodziwej władczyni

13 W tym kontekście warto przypomnieć, że oryginalny tytuł rękopisu Carrolla to Alice’s Adventures Under Ground.

14 Cytaty zgodne z polskimi napisami wydania DVD filmu Burtona. 
oraz pokonać smoka. Burtonowski Underland jest znacznie mroczniejszy od Carrollowskiego Wonderlandu; interpretując tę ekranizację, Hugh H. Davis (2016) określa wykreowany w niej świat jako „dystopijne pustkowie” (s. 147), wyniszczone i doprowadzone do upadku przez rządy tyranki, Czerwonej Królowej (Helena Bonham Carter).

Przeznaczeniem Alicji jest więc los mitycznego herosa: odniesienie zwycięstwa makrokosmicznego, decydującego o losach całego świata. Jak wskazuje Robyn McCallum (2018), „mogłoby się to wydawać powierzchowną próbą [...] ustanowienia heroicznej metanarracji zgodnej $\mathrm{z}$ oczekiwaniami mainstreamowej publiczności filmów Disneya" (s. 101) - widzowie mogliby zatem założyć, że mimo swoich protestów Alicja zgładzi potwora, pokona złą królową i pomoże wrócić na tron prawowitej władczyni. Jednakże, na co z kolei zwraca uwagę Jack Zipes (2011), w Burtonowskiej wizji być może najważniejsza bitwa rozgrywa się poza czy też ponad właściwą narracją zdaniem badacza, reżyser niejako stawia pytania m.in. o to, czy „młoda kobieta może pisać swoją własną opowieść” (s. 301). Stawką w heroicznej walce Alicji i celem mitycznej wędrówki, którą dziewczyna odbywa, jest bowiem własna tożsamość protagonistki, odwaga do samostanowienia i autonomia. Jednakże zanim bohaterka je odkryje, zdefiniuje i zdobędzie, musi przejść proces wewnętrznej metamorfozy, w którym będzie potrzebowała sprzymierzeńców. Mimo szeregu niepomyślnych zdarzeń - najazdu wojsk Królowej, utraty Rokrocznium, zranienia Alicji przez złowrogą bestię - protagonistka może liczyć na pomoc sił nadprzyrodzonych, pojawiających się, jak każe wzorzec monomitu, zawsze wtedy, gdy Alicja ich potrzebuje (Franke, 2015, s. 54), i prowadzących ją w dalszej wędrówce. Uosabia je m.in. Kot z Cheshire (Stephen Fry), który opatruje rany dziewczyny oraz umożliwia jej poznanie właściwego przewodnika po magicznym świecie - Szalonego Kapelusznika (Johnny Depp) $)^{15}$.

Pierwsze spotkanie z Kapelusznikiem odbywa się w czasie Obłędnej Herbatki, jednego z kluczowych elementów fabularnych tak powieści, jak i jej filmowego sequela. Rozmowy prowadzone przez bohaterów podczas tea time krążą wokół tożsamości Alicji oraz roli dziewczyny w wypełnieniu się przepowiedni. Szalony Kapelusznik jako jedyny żywi szczere przekonanie, że nowo przybyła jest wyczekiwanym wybawicielem. Obłędna Herbatka zostaje

15 Co ciekawe, Davis (2016, s. 144) uznaje za figurę heroiczną, kluczową dla obrazu Burtona, właśnie Szalonego Kapelusznika. Jakubowska (2015) natomiast dowodzi, że „w galerii Burtonowskich postaci najciekawszą pozostaje Szalony Kapelusznik. Kreacja aktorska John[ny’ego] Deppa wydobywa zarówno szaleństwo, jak i filozoficzną naturę tego bohatera” (s. 67). 
nagle przerwana przez najazd wysłanników Czerwonej Królowej. Alicję ratuje przed porwaniem jej mityczny przewodnik, który podejmuje się też misji zaprowadzenia dziewczyny przed oblicze Białej Królowej (Anne Hathaway), mając nadzieję, że ta pomoże jej wydostać się z zaczarowanej krainy. W czasie podróży nawiązuje się więź między protagonistką a Kapelusznikiem, który stara się przekonać swoją podopieczną do przyjęcia misji ocalenia magicznego świata. Odmowa i wyraźny sprzeciw Alicji odpowiadają temu, co Campbell (1949/1997, s. 55) określił w swojej koncepcji jako niezgodę wybrańca na podjęcie wyzwania. Szalony Kapelusznik usiłuje uzmysłowić dziewczynie zarówno zewnętrzne (uratowanie królestwa), jak i wewnętrzne powody, dla których powinna postąpić w zgodzie ze swoim przeznaczeniem:

Szalony Kapelusznik: Ty nie gładzisz?... A wiesz co tu wyczynia Czerwona Królowa?

Alicja: Nie umiem, choćbym chciała.

Szalony Kapelusznik: Zmieniłaś się od wtedy. Wtedy byłaś bardziej... bardziej... jesteś znacznie mniej Bardziej.

Alicja: Mniej Bardziej?

Szalony Kapelusznik: Tam w środku. Czegoś brakuje (Zanuck, Roth, Todd, Todd, Burton, 2010).

Punktem zwrotnym w fabule jest porwanie Szalonego Kapelusznika przez rycerzy Czerwonej Królowej. Poświęcając siebie na rzecz pomyślnego losu wybrańca (Alicji), przewodnik niejako zmusza dziewczynę do wykazania się inicjatywą w obliczu losu. Bohaterka podejmuje się heroicznej misji uratowania Kapelusznika - jednocześnie odrzucając wszystkie głosy jej pomocników namawiających ją do porzucenia tych niebezpiecznych planów. Alicja, paradoksalnie w akcie nieposłuszeństwa wobec swoich sprzymierzeńców, zaczyna brać świadomy udział w wydarzeniach, które w rezultacie doprowadzają ją do przejścia wewnętrznej przemiany.

Bernard: Czy jesteś może Alicją?

Alicja: Tak, ale nie tą, o której wszyscy mówią.

Bernard: Kapelusznik nie oddałby się w niewolę dla byle Alicji.

Alicja: Dokąd go zabrali?

Bernard: Do zamku Czerwonej Królowej w Salazen Grum.

Alicja: Wyciągniemy go.

Bernard: Tego nie ma w proroctwie.

Alicja: Co z tego? Pojmali go przeze mnie.

Bernard: Zbliża się Chwarny Dzień. Przygotuj się na bój z Żaberzwłokiem. 
Alicja: Odkąd wpadłam do nory, wciąż wysłuchuję, co mam robić i jaka być. Zmniejszacie mnie, powiększacie, wrzucacie do imbryka. Oskarżacie o bycie Alicją i o nie bycie nią. To mój sen. Odtąd ja decyduję, co będzie.

Bernard: Jeśli zboczysz z drogi...

Alicja: Drogę wyznaczam ja (Zanuck, Roth, Todd, Todd, Burton, 2010).

Poprzez swoją buntowniczą decyzję i nieuznawanie siebie samej za wybrańca, Alicja wytycza własną ścieżkę. Podjęcie się niebezpiecznej misji uwolnienia przyjaciela i przewodnika jest pierwszą decyzją, jaką dziewczyna podejmuje samodzielnie od początku opowieści. Sprzeciw wobec bycia sterowaną przez innych oraz dążenie do pełnej autonomii prowadzą bohaterkę do wypełnienia przeznaczonego jej losu. Wątpliwości, chaos myślowy i rozterki okazują się nieodłączną częścią poszukiwania własnego „ja” (Davis, 2016, s. 147).

Po dotarciu do zamku Czerwonej Królowej bohaterka ostatecznie uzmysławia sobie wagę nadziei pokładanych w niej samej, Alicji, przez mieszkańców magicznej krainy. Choć pierwotnym celem dziewczyny jest uwolnienie Szalonego Kapelusznika, ostatecznie podejmuje się nadrzędnej misji odnalezienia miecza Vorpalnego. Mimo swoich wcześniejszych protestów oraz kategorycznego odrzucania roli wybrańca, Alicja odkrywa w sobie odwage i determinację, aby stawić czoło wyjątkowemu niebezpieczeństwu. Jest to bardzo ważny etap z perspektywy Campbellowskiej koncepcji monomitu, gdyż jedynie poprzez pokonywanie kolejnych trudności bohater może wykazać się cechami predestynującymi go do roli wybrańca. Niczym w mitologicznej opowieści, miecza strzeże monstrum; Alicja staje oko w oko z potworem, który już raz czyhał na jej życie. Protagonistce udaje się pokonać swój własny strach, ale także wykazać się rozwagą oraz sprytem ${ }^{16}$. Nie stając do skazanej z góry na porażkę bitwy, Alicja obłaskawia potwora, przynosząc mu oko, które stracił w czasie poprzedniej potyczki. Zaskarbienie sobie przyjaźni bestii owocuje zdobyciem przez bohaterkę miecza, jednakże Szalony Kapelusznik pozostaje uwięziony. Alicja musi więc ponownie wyruszyć w drogę (teraz wspierana przez magiczną bestię), tym razem do zamku Białej Królowej, aby przekazać jej osławiony miecz.

16 McCallum (2018, s. 102) dowodzi, że wplatając w swoją autorską wizję Carrollowski (1871, s. 164) wiersz Jabberwocky, pozornie uprawomocniający narrację heroiczną, Burton w istocie ją podważa, traktuje bowiem ów wiersz na zasadzie subwersyjnej, intertekstualnej gry. Powołując się na rozważania Margery Hourihan (1997, s. 206), badaczka stwierdza, że treść poematu Jabberwocky stanowi dekonstrukcję tradycyjnego modelu męskości, uwydatnia bowiem absurd etosu heroicznego, zgodnie z którym głównym celem życia bohatera jest znalezienie czegoś, co można zabić. 
Choć Alicja ponownie odmawia przyjęcia misji uwolnienia krainy od smoka, Królowej udaje się namówić bohaterkę do kolejnej rozmowy z mitycznym mędrcem:

Absolem: Kim jesteś?

Alicja: Już to ustaliliśmy. Jestem Alicją. Nie tą, co trzeba.

Absolem: Skąd wiesz?

Alicja: Tak powiedziałeś.

Absolem: Mówiłem, że jesteś wątpliwie. Zmieniłaś się jednak. Teraz jesteś Alicją nieomal.

Alicja: Nie zgładzę Żaberzwłoka choćby zależało od tego moje życie.

Absolem: A będzie. Miej Turpi Koncerz pod ręką, gdy Chwarny Dzień zaświta (Zanuck, Roth, Todd, Todd, Burton, 2010).

Zgodnie z perspektywą mityczną bohater rodzi się nie jako wybraniec, lecz jako osoba predestynowana do odbycia określonej wyprawy. Dlatego też staje się wybrańcem dopiero poprzez wypełnianie poszczególnych zadań oraz pokonywanie kolejnych przeszkód. Rozmowa pomiędzy Alicją i Absolemem wskazuje na ten bardzo ważny element rozwoju bohatera mitycznego. Przekraczając granicę rzeczywistości, trafiając do Krainy Czarów, Alicja nie staje się automatycznie herosem, wyczekiwanym wybrańcem. Dziewczyna niejako wydobywa wybrańca $\mathrm{z}$ samej siebie, właśnie poprzez udział w wyprawie bohaterskiej.

Nadejście dnia Bardosnego to decydujący moment w transgresyjnej wędrówce Alicji. Postawiona przed obliczem Białej Królowej oraz jej poddanych, dziewczyna nie potrafi ostatecznie zadecydować, czy jest gotowa podjąć się walki ze smokiem. Aby podkreślić wagę rozdarcia wewnętrznego bohaterki, warto zauważyć, że jej nieumiejętność podjęcia decyzji przebiega paralelnie pomiędzy światem rzeczywistym a magicznym. Uciekając z przyjęcia zaręczynowego, Alicja odwleka konfrontację z oczekiwaniami rodziny; w świecie magicznym, uciekając sprzed oblicza Królowej, odwleka zaś konfrontację z własnym przeznaczeniem. Owa nieumiejętność nie wypływa jedynie z niechęci, jaką bohaterka żywi wobec oczekiwań innych, lecz przede wszystkim z niezdolności do określenia samej siebie jako dojrzałej osoby. Mimo zapisanej na pergaminie legendy, Alicja musi samodzielnie dotrzeć do prawdy o przeznaczonej jej roli. Podjęcie wyzwania, przyjęcie misji ocalenia Krainy Czarów, pokonanie smoka - każda z tych decyzji przybliża bohaterkę do osiągnięcia wewnętrznej dojrzałości i autonomii. Biała Królowa przekonują ją: „Nie pozwól, by inni tobą kierowali. Decyzję musisz podjąć sama. Bo jeśli staniesz do walki, nie będzie przy tobie nikogo" (Zanuck, Roth, Todd, Todd, Burton, 2010). 
Po ucieczce do zamkowych ogrodów Alicja napotyka przepoczwarzającego się Absolema. Rozmowa pomiędzy zagubioną dziewczyną a przechodzącą przemianę w motyla Gąsienicą zdaje się kolejnym punktem zwrotnym opowieści. Ów proces transformacji symbolicznie rozciąga się również na protagonistkę. Oboje bohaterowie doświadczają inicjacji w nowy etap życia:

Alicja: Czemu wisisz do góry nogami?

Absolem: To życie dobiega dla mnie końca.

Alicja: Umierasz?

Absolem: Przepoczwarzam się.

Alicja: Nie odchodź. Co mam robić? Pomóż mi.

Absolem: Jak? Nawet nie wiesz[,] kim jesteś, tępe dziecię.

Alicja: Nie jestem tępa. Mam na imię Alicja. Mieszkam w Londynie. Jestem córką Heleny i siostrą Małgorzaty. Moim ojcem był Karol Kingsleigh. Jego fantazja nie znała granic i nie obawiał się niczego. Jestem jego córką. Alicją Kingsleigh.

Absolem: Alicjo, nareszcie. Zbytnio nie zmądrzałaś. Wtedy mówiłaś, że to Kraina Czarów.

Alice: Kraina Czarów? (Zanuck, Roth, Todd, Todd, Burton, 2010).

Przemiana głównego bohatera, będąca celem oraz najważniejszym elementem monomitu (a w związku z tym - każdej opowieści mitycznej), w ekranizacji Burtona ukazana zostaje w scenie, w której dziewczyna przypomina sobie swój czynny udział w wydarzeniach, które rozegrały się w Krainie Czarów trzynaście lat wcześniej, przez co odnajduje utraconą część tożsamości. Zyskanie samoświadomości, wewnętrzna metamorfoza, odnalezienie własnego ,ja” - to wyzwania, którym musi sprostać bohater mityczny. Droga, jaką przebywa Alicja, znajduje swój finał właśnie w wewnętrznej przemianie dziewczyny, w transgresji z zagubionej panienki w odważną wojowniczkę o własną autonomię. Przeszkody zostają pokonane, przepowiednia się wypełnia, rodzi się bohater:

Alicja: To nie był sen, ale wspomnienie. To wszystko jest naprawdę. Istniejesz ty i Kapelusznik.

Absolem: Jak i Żaberzwłok. Pamiętaj, Turpi Koncerz wie, czego chce. Masz tylko nie wypuścić go z ręki (Zanuck, Roth, Todd, Todd, Burton, 2010).

Zgodnie z monumentalnym charakterem opowieści Burtona, finałowa bitwa odbywa się na polu szachowym, gdzie naprzeciwko siebie stają wojska Czerwonej oraz Białej Królowej. Alicja, jak przystało na bohatera mitycznego, musi wypełnić przeznaczoną jej rolę i pokonać wroga smoka Żaberzwłoka - Vorpala. Co istotne, walka dwóch zwaśnionych stron w gruncie rzeczy toczy się 
pomiędzy dwiema odwiecznymi, przeciwstawnymi mocami: dobrem i złem. Ostatecznie zwyciężają siły dobra. Zgodnie z optyką mityczną Alicja odnosi zwycięstwo makrokosmiczne - zło zostaje pokonane, równowaga w świecie - przywrócona, a kraina zostaje uwolniona spod rządów Królowej. Protagonistce udaje się ocalić cały świat, na wzór najważniejszych opowieści mitycznych. Przeznaczenie Alicji, jej rola jako wybawczyni magicznej krainy splatają się z losem tej bohaterki w świecie rzeczywistym. Przemiana, jaką dziewczyna przechodzi w Underlandzie, jest niezbędna w realnym życiu. Gdyby proces inicjacji nie zakończył się pomyślnie, Alicja nie mogłaby powrócić do świata, z którego przybyła. Wyzwolenie magicznej krainy jest równoznaczne z uwolnieniem się od własnych ograniczeń.

Transgresyjna wędrówka po Krainie Czarów dobiega końca. Szalony Kapelusznik namawia Alicję do pozostania, jednakże jej misja w tym świecie została już wypełniona. Uzyskawszy pełnię człowieczeństwa, bohaterka musi powrócić do świata empirycznego, by zmierzyć się z realnymi problemami i decyzjami (dotyczącymi zaręczyn oraz pokierowania interesami ojca). Historia zatacza koło: Alicja rozumie, że opuszczenie Krainy Snów wiąże się z ponowną utratą pamięci o przeżyciach w tym niezwykłym świecie - jak wtedy, gdy odwiedziła go po raz pierwszy, jako dziecko. Pijąc krew smoka, bohaterka dopełnia swojego przeznaczenia, co kończy drugi, najdłuższy etap monomitu: etap inicjacji. Alicja powraca przez króliczą norę do świata rzeczywistego, który, w przeciwieństwie do niej samej, nie zmienił się znacząco. Powrót to ostatni etap monomitu. $Z$ niepewnej siebie, zagubionej dziewczyny, Alicja niczym Absolem przeistacza się w nową, lepszą, odważniejszą wersję samej siebie. Śmiało podejmując kolejne decyzje, odrzuca zaręczyny nieinteresującego ją mężczyzny i wbrew oczekiwaniom wszystkich krewnych postanawia podążyć za swoim instynktem i wyruszyć świat, tak jak uczynił kiedyś jej ojciec - kolejne wyzwanie podejmie dopiero po powrocie z podróży, w drugiej części filmowego cyklu (Roth, Todd, Todd, Burton, Bobin, 2016).

Analiza scenariusza Burtonowskiego wariantu historii o Alicji w Krainie Czarów wskazuje, że ekranizacja ta wyraźnie nawiązuje do archetypowej opowieści mitycznej. Wykorzystując koncepcję Campbella, można by zresztą badać także inne XXI-wieczne adaptacje czy też renarracje dzieła Carrolla, których twórcy nadali Alicji cechy mitycznego herosa, jak np. powieść Geny Showalter (2012/2013) Alicja $w$ krainie zombie, serial Once Upon a Time in Wonderland (Kitsis, Horowitz, Estrin, Espenson, 2013-2014) wyprodukowany przez amerykańską stację ABC czy też cykl powieściowy The Looking Glass Wars Franka Beddora $(2005,2007,2010)$. Burton natomiast, poprzez wplecenie w przygody Carrollowskiej bohaterki struktury monomitu, niejako buduje pomost pomiędzy 
starożytną tradycją opowieści mitycznej a współczesnym filmem kierowanym do dzieci, młodzieży i młodych dorosłych. Poruszając kwestie istotne dla młodego człowieka (kim jestem, dokąd dążę, jak chcę pokierować swoim życiem?), poddaje je refleksji na głębszym, mitycznym poziomie. Jednocześnie, poniekąd również dzięki inspiracjom koncepcją Campbella, tworzy fascynujące estetycznie widowisko, szczególnie interesujące dla potencjalnego widza - „[...] dla twórców filmowych monomit jako schemat fabularny jest wyjątkowo atrakcyjny - otwiera możliwość realizacji zdjęć w widowiskowych lokalizacjach, budowania spektakularnych scen akcji czy wykorzystania nowatorskich technologii" (de Oliveira, 2017, s. 182); i rzeczywiście - film Burtona spełnia wszystkie te warunki.

Charakterystyczna dla dzieła Carrolla „otwartość i wieloznaczność okazuje się nieustannym zaproszeniem do powrotów”, jak pisała badaczka analizująca rozmaite adaptacje Alicji... (Jakubowska, 2015, s. 70). Toteż film Burtona wydaje się takim właśnie powrotem w podwójnym sensie: reżyser zafascynowany literackim pierwowzorem powraca do Krainy Czarów, by zrekonstruować ją zgodnie z własną artystyczną wizją; na poziomie metanarracyjnym zaś Alicja powraca przez króliczą norę do niezwykłego świata, by odbyć swoją mityczną, inicjacyjną wędrówkę.

\section{Bibliografia}

Beddor, F. (2005). The Looking Glass wars. London: Egmont.

Beddor, F. (2007). Seeing Redd. London: Egmont.

Beddor, F. (2010). ArchEnemy. London: Egmont.

Bovaird-Abbo, K. (2014). Neglected yet noble: Nyneve and female heroism in Thomas Malory's Le morte darthur. W: L. M. Campbell (red.), A quest of her own: Essays on the female hero in modern fantasy (s. 35-54). Jefferson, NC: McFarland.

Brooker, W. (2004). Alice's adventures: Lewis Carroll in popular culture. New York, NY: Continuum.

Campbell, J. (1997). Bohater o tysiącu twarzy (A. Jankowski, tłum.). Poznań: Zysk i S-ka. (wyd. oryg. 1949).

Carroll, L. (1865). Alice's adventures in Wonderland. London: Macmillan.

Carroll, L. (1871). Through the Looking Glass, and what Alice found there. London: Macmillan.

Davis, H. H. (2016). 'The real Alice?': Memory and adaptation in Tim Burton's Alice in Wonderland. W: S. Helff, N. Butt (red.), 'Tantalizing Alice': Approaches, concepts and case-studies in adaptations of a classic (s. 141-154). Trier: WVT.

De Oliveira, W. (2017). Hedonizm imaginatywny, kino postfabularne i przestrzeń wyzwolona z narracji. Hobbit Petera Jacksona. Dyskurs, 23, 172-195. 
Disney, W. (prod.), Geronimi, C., Jackson, W., Luske, H. (reż.). (1951). Alice in Wonderland [Alicja w Krainie Czarów]. USA: Walt Disney Productions, RKO Radio Pictures.

Franke, A. (2015). Filmy Matrix oraz Alicja w Krainie Czarów jako archetypiczne opowieści mityczne. Warszawa: Wydawnictwo SBP.

Fueter, P.-C. (prod.), Švankmajer, J. (reż.). (1988). Něco z Alenky [Coś z Alicji]. Czechosłowacja, Szwajcaria, Wielka Brytania, RFN, Związek Radziecki: Film Four International, Condor Films, First Run Features.

Helff, S., Butt, N. (red.). (2016). 'Tantalizing Alice': Approaches, concepts and case-studies in adaptations of a classic. Trier: WVT.

Hourihan, M. (1997). Deconstructing the hero: Literary theory and children's literature. London, New York, NY: Routledge.

Jakubowska, M. (2015). Alicja w krainie słów i obrazów. W: A. Izdebska, D. Szajnert (red.), Literatura prze-pisana. Od Hamleta do slashu (s. 53-71). https://doi. org/10.18778/7969-644-4.05.

Kérchy, A. (2016). Alice in transmedia Wonderland: Curiouser and curiouser new forms of a children's classic. Jefferson, NC: McFarland.

Kitsis, E., Horowitz, A., Estrin, Z., Espenson, J. (prod.). (2013-2014). Once upon a time in Wonderland [serial telewizyjny]. Burbank, CA: ABC.

Kostecka, W. (2014). Baśń postmodernistyczna: przeobrażenia gatunku. Intertekstualne gry $z$ tradycja literacką. Warszawa: Wydawnictwo SBP.

Kowalczyk, K. (2014). Przed „dawno, dawno temu” i po „żyli długo i szczęśliwie” o filmowych i komiksowych prequelach i sequelach na przykładzie Jasia i Małgosi braci Grimmów. Literatura Ludowa, 4/5(58), 39-49.

Kowalczyk, K. (2016). Baśń w zwierciadle popkultury. Renarracje baśni ze zbioru Kinder- und Hausmärchen Wilhelma i Jakuba Grimmów w przestrzeni kultury popularnej. Wrocław: Stowarzyszenie Badaczy Popkultury i Edukacji Popkulturowej „Trickster”, Polskie Towarzystwo Ludoznawcze.

Lasoń-Kochańska, G. (2005). Kora, Demeter i inne. Córki ojców, córki matek. Stupskie Prace Filologiczne. Seria Filologia Polska, 4, 189-200.

Łucyk, W. (2017). Walter White vs. Wielki Mechanizm. Breaking Bad jako serial szekspirowski. W: D. Bruszewska-Przytuła, M. Cichmińska, A. Krawczyk-Łaskarzewska, A. Naruszewicz-Duchlińska (red.), Seriale w kontekście kulturowym. Dyskurs, konwencja, reprezentacja (s. 54-62). Olsztyn: Instytut Polonistyki i Logopedii UWM.

McCallum, R. (2018). Screen adaptations and the politics of childhood: Transforming children's literature into film. https://doi.org/10.1057/978-1-137-39541-2.

Murdock, M. (1990). The heroine's journey: Woman's quest for wholeness. Boston, MA: Shambhala.

Musiał, Ł. (2016). Proces - co nowego? Przeglad Humanistyczny, 4(455), 83-94. 
Nichols, C. (2014). Alice's Wonderland: A visual journey through Lewis Carroll's mad, mad world. New York, NY: Race Point.

Nicholson, S. (2011). The problem of woman as hero in the work of Joseph Campbell. Feminist Theology, 19(2), 182-193. https://doi.org/10.1177\%2F0966735010384331.

Propp, W. (2011). Morfologia bajki magicznej (P. Rojek, tłum.). Kraków: Nomos. (wyd. oryg. 1928).

Roth, J., Todd, S., Todd, J., Burton, T. (prod.), Bobin, J. (reż.). (2016). Alice through the Looking Glass [Alicja po drugiej stronie lustra] [film]. USA: Walt Disney Studios Motion Pictures.

Showalter, G. (2013). Alicja w krainie zombie (J. Kabat, tłum.). Warszawa: Harlequin Polska. (wyd. oryg. 2012).

Skowera, M. (2016). Postmodernistyczny retelling baśni - garść uwag terminologicznych. Creatio Fantastica, 2(53), 48-49.

Sundmark, B. (1999). Alice's adventures in the oral-literary continuum. Lund: Lund University Press.

Tarnogórska, M. (2016). Podwójne życie Alicji, czyli Kraina Czarów w kulturze literackiej i naukowej. W: A. Izdebska, A. Przybyszewska, D. Szajnert (red.), Literatura prze-pisana II. Od zapomnianych teorii do kryminału (s. 53-67). https://doi. org/10.18778/8088-214-0.04.

Ungeheuer-Gołąb, A. (2014). Dziewczynka, która uskrzydliła wyobraźnię. O Alicji w Krainie Czarów Lewisa Carrolla. W: B. Niesporek-Szamburska, M. Wójcik-Dudek, A. Zok-Smoła (red.), Wyczytać świat - międzykulturowość w literaturze dla dzieci i młodzieży (s. 125-141). Katowice: Wydawnictwo UŚ.

Vogler, C. (2009). Podróż autora. Struktury mityczne dla scenarzystów i pisarzy (K. Kosińska, tłum.). Warszawa: Wydawnictwo Wojciech Marzec. (wyd. oryg. 1992).

Zanuck, R. D., Roth, J., Todd, S., Todd, J., (prod.), Burton, T. (reż.). (2010). Alice in Wonderland [Alicja w Krainie Czarów] [film]. USA: Walt Disney Studios Motion Pictures.

Zipes, J. (2011). The enchanted screen: The unknown history of fairy-tale films. New York, NY, London: Routledge.

Zipes, J. (2016a). Beyond Disney in the twenty-first century: Changing aspects of fairy-tale films in the American film industry. W: J. Zipes, P. Greenhill, K. Magnus-Johnston (red.), Fairy-tale films beyond Disney: International perspectives (s. 278-293). New York, NY, London: Routledge.

Zipes, J. (2016b). The great cultural tsunami of fairy-tale films. W: J. Zipes, P. Greenhill, K. Magnus-Johnston (red.), Fairy-tale films beyond Disney: International perspectives (s. 1-17). New York, NY, London: Routledge.

Żurek, W. (2010). Gwiezdne wojny w perspektywie strukturalnej i poststrukturalnej. W: A. Jawłowski (red.), Dawno temu w Galaktyce Popularnej (s. 152-165). Warszawa: Wydawnictwa Akademickie i Profesjonalne. 